Vol. 7, No. 1, 2020

https://doi.org/10.23939/eem2020.01.035

UDC 657: 339.137 (477.87)

JELClasification Code: M41

\author{
V. Shvets \\ Ivan Franko National University of Lviv, Ukraine, PhD, Professor \\ E-mail: shwe@ukr.net \\ ORCID: 0000-0002-9940-689X
}

\title{
ACCOUNTING AND ANALYTICAL PROBLEMS OF CULTURAL HERITAGE SECURITY IN POLISH-UKRAINIAN CROSS-BORDER COOPERATION
}

\begin{abstract}
The safety of cultural heritage in a cross-border dimension depends significantly on the influence of accounting and analytical factors, as they form the basis for the perception of its objects for their proper preservation and constant monitoring of the state and risks of irreversible changes. This issue is especially important in Polish-Ukrainian cross-border cooperation, where historical realities have led to the destruction and destruction of many cultural heritage sites. Accounting and analytical problems of cultural heritage safety arise both in connection with the lack of theoretical and methodological studies of these issues and due to the imperfection of the legal and regulatory field, especially in Ukraine. It is substantiated that the main problem of theoretical and methodological character is the lack of studies aimed at developing a standard system of perception of cultural heritage objects in the PolishUkrainian border area. The results of the analysis of the main criteria of the system of perception used in accounting for cultural heritage objects, the example of intangible monuments, the absence of scientifically substantiated species and varieties, which complicates the use of standard methods and techniques of accounting and analytical nature. First of all, the standardization of the classification parameters of cultural heritage objects, taking into account the national priorities of Ukraine and Poland, requires scientific study. It is also established that the positive changes made in recent years in the legal support for the preservation of the common cultural heritage have in their tools accounting and analytical aspects that can significantly affect their objective perception for exercising constant control. In the context of solving accounting and analytical problems, it is necessary to develop a methodology for objective evaluation of cultural heritage objects, taking into account the
\end{abstract}

prospect of world cultural and historical progress. Addressing these issues also involves taking into account the achievements of Poland in the classification of cultural and historical sites, as well as those initiatives for the protection of the common cultural and historical heritage concerning sites located in the adjacent border area.

Key words: accounting and analytical issues, cultural heritage, Polish-Ukrainian cross-border cooperation, security.

Formulation of the problem.

The security of cultural heritage in PolishUkrainian cross-border cooperation is one of the problems of security of Ukraine as a young state. Moreover, its solution requires a number of measures, including transboundary nature, which are first and foremost related to the accounting and analytical support of cultural heritage objects in order to control their condition and preservation.

\section{Topicality of the chosen topic.}

The availability of accounting and analytical support allows to form an effective economic and legal basis for the perception, evaluation and registration of cultural heritage objects. After all, the accounting, analysis and control of cultural heritage objects must be organized in such a way as to cover all valuable cultural and historical monuments in order to preserve them properly. Particular relevance of this issue is evident in Polish-Ukrainian relations. As the common historical past of Poland and Ukraine has been subject to different situations as a result of political 


\section{Shvets}

and economic reasons. One of the worst consequences has been the destruction and destruction of many cultural heritage sites on both sides of today's border. Therefore, the cross-border cooperation between Poland and Ukraine on the preservation of cultural heritage is in the forefront of the most intellectual potential of both nations.

Analysis of recent research and publications.

Despite increasing attention to this issue by scholars, central government and local communities, the organizational, methodological and legal foundations of preserving cultural and historical values are unable to provide an effective mechanism for their safety. Thus, at the 2017 International Conference organized and funded through the Poland-Belarus-Ukraine Cross-Border Cooperation, these issues were addressed from the point of view of improving control over the preservation of cultural and historical values [1]. V. Geyets, V. Gnyp, M. Karaim, M. Kizim, T. Klebanova, Y. Kotlyarevsky, H. Mandzinovskaya, O. Melnikov, L. Sukhomlin, O. Khalina, O. Chernyak, A. Stangret and many others paid attention to safety issues of economic entities in their works [2]. However, these studies did not sufficiently address the issues of cultural heritage security, and in particular in the cross-border dimension [3]. Continuing research on the conservation of cultural and historical values requires not only new realities of time, but also identified problems of accounting and analytical nature, without which it is impossible to provide an effective mechanism for their safety and avoid the risk of damage and loss.

\section{Purpose and tasks.}

The purpose of the study is to address accounting and analytical issues that have an impact on the security of cultural heritage in Polish-Ukrainian cross-border cooperation. Achieving this goal involves solving a specific range of tasks, namely: to find out the essence of the problem and outline the tasks of the central bodies of legislative and executive power to preserve cultural heritage; analyze the cause and effect relationships of the occurrence and existence of accounting and analytical problems in the field of cultural and historical heritage conservation; to find out the content of accounting and analytical problems of objects of intangible cultural heritage; to determine the possibilities of solving accounting and analytical problems of cultural heritage safety, taking into account the experience of Poland, as well as joint initiatives concerning the preservation and protection of the common cultural and historical heritage in the border area; to conduct a survey among students of the specialty "Education and taxation" on cultural and historical heritage and trade in antiques.

\section{Outline of the main research material and the obtained results.}

It is well known that accounting and analytical problems of cultural heritage safety arise from the lack of theoretical and methodological studies of these issues and the imperfection of the legal field, on the one hand, and their adequacy in ensuring the activities of organizations in Poland and Ukraine - on the other. As the basics of accounting methodology are grounded in the legal framework, legislative measures are required to safeguard cultural heritage. Museums played an important role in the formation of an effective legal field, with regard to the preservation of cultural and historical values in Ukraine. Thus, in the Open Letter of the Museum and Monumental Community of Ukraine dated May 9, 2019, representatives of 118 museums and reserves from all regions of Ukraine and representatives of more than 20 scientific institutions and educational institutions, as well as professional branch organizations addressed the head of the Verkhovna Rada and MPs on the occasion of International Museum Day, celebrated on May 18. The complaint noted an unpleasant misunderstanding that lasted more than a year (April 18, 2018). It was then that the Verkhovna Rada of Ukraine hosted parliamentary hearings on "The state, problems and prospects of cultural heritage protection in Ukraine" [4]. Following these hearings, appropriate comprehensive recommendations were developed for the executive and local self-government bodies on the protection of cultural property. The recommendations covered all issues pertaining to the protection of cultural heritage sites, their restoration, the fight against the illicit circulation of cultural property, the development of international cooperation, the promotion of Ukrainian history, 
and the legislative support for the protection and protection of cultural heritage. However, at the time of writing the aforementioned open letter, these Recommendations were not considered by the Verkhovna Rada for adoption of the relevant resolution, although 17 times were included on the agenda. Under the influence of the museum and monumental community, as well as the upcoming elections, this issue was considered on May 14, 2019 and a resolution was adopted [5]. The adopted Resolution corresponds to the content of Article 54 of the Constitution of Ukraine, which states: "the State shall ensure the preservation of historical monuments and other objects of cultural value, take measures to return to Ukraine cultural values of the people outside its borders" [6]. At the same time, the versatility and diversity of cultural heritage sites in Ukraine are represented by a wide range of objects, namely: immovable cultural and historical sites, museum and archival values, monuments of folk art and collectibles. At the same time, the declared intentions need substantive detail regarding the accounting and analytical support for the formation of the economic security system for the preservation of cultural heritage. In the context of the identified tasks of the President of Ukraine, the Verkhovna Rada and the Cabinet of Ministers, the contours of accounting and analytical issues that clearly need to be resolved are clearly manifested. Moreover, the sooner these issues become clear and legal, the sooner the mechanism for preserving cultural heritage will work. Thus, the President of Ukraine is tasked with submitting to the Verkhovna Rada of Ukraine a draft law of Ukraine on the accession of Ukraine to the Second Protocol to the Convention on the Protection of Cultural Property in the Event of Armed Conflict signed in The Hague as early as 1954 . However, these issues concern Crimea and eastern Ukraine. however, information support for future actions under this Convention will be based solely on accounting and analytical data on cultural and historical heritage sites. Accordingly, accounting and analytical information should conform to the standard classification of such values, and their valuation should be determined on the basis of generally recognized and acceptable worldwide methods.

The Verkhovna Rada of Ukraine is tasked with ensuring the consideration and adoption of a number of laws containing issues of accounting and analytical support (Table 1).

\section{Issues of accounting and analytical character on the protection of cultural heritage in the changes to the laws of Ukraine}

\begin{tabular}{|c|l|l|}
\hline No. & \multicolumn{1}{|c|}{ The essence of change } & Accounting and analytical aspects \\
\hline 5677 & Increasing responsibility in the field of cultural heritage protection & Object classification and evaluation \\
\hline 5679 & Prohibition of outdoor advertising on cultural heritage sites & Object recognition \\
\hline 6765 & $\begin{array}{l}\text { Unification of the mechanism of establishing and strengthening } \\
\text { administrative responsibility for violation of the requirements of the } \\
\text { legislation on protection of cultural heritage }\end{array}$ & Estimation of damages caused \\
\hline 6769 & $\begin{array}{l}\text { Strengthening of state supervision (control) in the field of cultural } \\
\text { heritage protection }\end{array}$ & $\begin{array}{l}\text { Control options, accounting for } \\
\text { changes and moves }\end{array}$ \\
\hline 8050 & $\begin{array}{l}\text { Increasing criminal responsibility for crimes in the field of cultural } \\
\text { heritage protection }\end{array}$ & Object classification and evaluation \\
\hline 8202 & $\begin{array}{l}\text { Determining the procedure for the forced redemption of cultural } \\
\text { objects if the owners, through their actions or omissions, contribute } \\
\text { to their destruction }\end{array}$ & Estimation of damages caused \\
\hline 8314 & Combating the illegal seizure of archaeological sites & Object accounting, analysis and control \\
\hline
\end{tabular}

As can be seen from Table 1, the Verkhovna Rada of Ukraine needs to ensure consideration and adoption of a number of laws, first of all, on strengthening of responsibility in the field of cultural heritage protection, as well as prohibition of unauthorized use of such objects, for example for outdoor advertising on cultural monuments. heritage. That is, the amendments relate to the 


\section{Shvets}

Code of Administrative Offenses, the Criminal Code of Ukraine and the Law of Ukraine "On Protection of Cultural Heritage". Particular attention is paid to amendments to the Law of Ukraine "On Basic Principles of State Supervision (Control) in the Field of Economic Activity" on Cultural Heritage Sites, including the Definition of the Procedure for Compulsory Redemption of Cultural Heritage Sites if Owners With Their Actions or Inaction their destruction. An example of such situations is the leasing of some ancient castles in the Lviv region when the tenant fails to fulfill his or her obligations to preserve and restore cultural heritage objects [1]. Also important are changes to some Ukrainian legislation to counteract the illegal seizure of archaeological sites. All these changes include accounting and analytical aspects that relate, first and foremost, to the classification of cultural and historical values, valuation methods and methods of determining the loss of cultural heritage objects.

The third group of tasks, jointly identified by the Verkhovna Rada and the Cabinet of Ministers of Ukraine on cultural heritage preservation, envisages four main areas of activity (Table 2).

Table 2

Main directions of joint activity of the Verkhovna Rada and the Cabinet of Ministers of Ukraine for the preservation of cultural heritage and their accounting and analytical aspects

\begin{tabular}{|c|c|c|}
\hline No. & Directions & Accounting and analytical aspects \\
\hline 1 & $\begin{array}{l}\text { Develop and adopt laws to prevent the archaeological exploration } \\
\text { of archaeological sites, the status of private collections, and } \\
\text { harmonize legislation in the field of museums with international } \\
\text { norms and best European practices }\end{array}$ & $\begin{array}{lll}\text { Accounting } & \text { and registration } & \text { of } \\
\text { artifacts, } & \text { standardization } & \text { of } \\
\text { classification features } & \end{array}$ \\
\hline 2 & $\begin{array}{l}\text { Ensure the harmonization of cultural heritage legislation with urban } \\
\text { planning legislation }\end{array}$ & $\begin{array}{l}\text { Accounting and registration of } \\
\text { cultural objects }\end{array}$ \\
\hline 3 & $\begin{array}{l}\text { Provide funds in the State Budget of Ukraine (from 2019) to create } \\
\text { an electronic information resource for cultural heritage and cultural } \\
\text { values }\end{array}$ & $\begin{array}{l}\text { Classification of cultural property, } \\
\text { their evaluation and inventory }\end{array}$ \\
\hline 4 & $\begin{array}{l}\text { Introducing preferential taxation in the field of cultural heritage } \\
\text { protection and preferential lending from the state and local budgets } \\
\text { for the restoration works on the objects of cultural heritage, } \\
\text { creating a system of incentives for conscientious owners of } \\
\text { monuments }\end{array}$ & $\begin{array}{l}\text { Accounting and registration of } \\
\text { objects of cultural heritage and } \\
\text { development of criteria for activities } \\
\text { that give rise to the right to tax } \\
\text { exemption }\end{array}$ \\
\hline
\end{tabular}

As can be seen from the table. 2, there is a need to adopt laws to prevent the illegal conduct of archaeological prospecting, excavations, and underwater work on archaeological heritage sites. This need is driven by the rapid growth rate of private archeological exploration compared to the activities of official archeological expeditions funded on a residual basis inherited in the postsocialist legal space. The adoption of such a law should not be prohibitive in nature but purely stimulating, since private archaeological sites are more efficient because of their technical equipment. The prohibition of private archeological activity does not solve the problem of unauthorized exploration, but only distorts relations in the market of antiques and cultural values, stimulating the development of a shadow economy. The formation of a legislative field, taking into account world best practices, should create the conditions for private archaeologists to be most interested in selling cultural property to state museums and archives. At the same time, such activities should be monitored for the purpose of providing information for scientific research. That is, found artifacts should be recorded in a single register of cultural and historical values and displacement. It is in this part that there is a need for a standard classification of cultural heritage sites that is in line with national best practices. Of particular concern is the need to regulate the legal status of private collections, as stated in the Decree. In our opinion, the consolidation of the status of private collections 
in the legislative field should be based on the principle of their national identity in the treasury of the world cultural heritage. It is well known that a comprehensive themed collection is valued as the sum of the value of the individual items and the cost of the subject's efforts on the one hand, and the uniqueness of this collection nationally and globally. It is impossible to compare the Roman Empire coin collection with the coin collection of Kievan Rus . Since the collection of Picasso drawings with the collection of Trypillian culture artifacts are not allowed in the juxtaposed. There is a lack of officially recognized experts in Ukraine, and foreign experts are not able to fully assess the collections in the context of their value to the national cultural heritage. There is no such problem in highly developed countries, as state museums have the exclusive right to purchase the most valuable collections and individual objects. Moreover, this is done transparently and no shadow schemes are possible here. Collections of transboundary importance, for example for the Ukrainian and Polish peoples, deserve special attention in the legislative field, which should also be reflected in the relevant law.

This area of joint activity of the legislative and executive power in Ukraine should be accompanied by the harmonization of legislation in the field of museum work both in Poland and international norms and with the best European experience. Recognition and adherence to the ICOM Museum Ethics Code should be the basis for cross-border cooperation in the preservation of the common Polish-Ukrainian heritage, as well as in accordance with the system of professional ethical standards adopted by both states.

An important element in the formation of the system of cultural heritage preservation, including in the cross-border dimension, is the development of a mechanism for channeling funds received as financial sanctions for damage caused by violation of the legislation on protection of cultural heritage due to economic and other activities or inactivity to special funds of state and local budgets. with their purpose for events, for the preservation and restoration of cultural objects. Such financial support for cultural heritage conservation work requires appropriate accounting and analytical support to prevent abuse and create real incentives to maintain the cultural heritage in proper condition.
One of the competences of the joint activity of the Verkhovna Rada and the Cabinet of Ministers of Ukraine is the issue of promoting patronage and volunteering in the field of cultural heritage protection. The material and intangible heritage must be taken into account here. Recognition and confirmation of philanthropy should be based on objective facts and not on economic and other benefits. This requires accounting and analytical support that would make it impossible to overestimate or underestimate the real effects of philanthropic activities and provide information about the fair contribution of their originators.

As can be seen from Table 2, the second area of joint activity of the legislative and executive power is to ensure the harmonization of the legislation on the protection of cultural heritage with the legislation on urban development. The main purpose of these actions is to prevent the transfer of objects of cultural and historical heritage into an uncontrolled environment, and the statutory liability would provide for criminal liability of guilty officials without a limitation period and mitigating circumstances. It is a matter of practically irreversible destruction of cultural objects and such actions should be classified as socially dangerous. As a control parameter should be a single register of objects of historical and cultural heritage of Ukraine. The Register of Cultural and Historical Heritage Sites should include tangible and intangible objects that are also related to the activities of Ukrainian statesmen, biasedly ignored or forgotten in times of repression against the Ukrainian people, with constant updating. Keeping a single registry must be linked to scientific research on national cultural and historical heritage and biographies of prominent figures of Ukraine. In the cross-border cooperation with Poland, it is advisable to conduct an annual bilateral exchange of information on the changes made to the Single Registry in the form of a permanent conference.

The logical continuation of the previous task of creating a single register of cultural and historical values is the direction of legitimizing permanent financial support. That is, it is necessary 


\section{Shvets}

to allocate funds in the State Budget of Ukraine for the creation of an electronic information resource of cultural heritage and cultural values. In accounting and analytical perspective, the successful implementation of this project requires a single scientifically sound classification of cultural values, a standard methodology for their accounting and evaluation in the process of conducting an annual inventory.

The fourth direction of the joint activity of the Verkhovna Rada and the Cabinet of Ministers of Ukraine is to study the issues of preferential taxation in the field of cultural heritage protection, as well as preferential lending from the state and local budgets for carrying out restoration works on objects of cultural heritage. That is, it is necessary to create a system of incentives for conscientious owners and users of cultural and historical monuments, the mechanism of which would ensure the preservation of cultural heritage in Ukraine. In the accounting and analytical aspect, the standardized accounting and registration of cultural objects - on the one hand, and, the development of criteria for which the right to benefit from taxation on the other. The creation of an electronic register of the results of annual activities for the maintenance of objects of cultural and historical heritage should be based on the reporting information received from economic entities in the relevant section. For example, there may be the following options: 1 . Income and expenses from the use of cultural and historical heritage; 2. Funds spent on maintenance and improvement of the state of the objects of cultural and historical heritage; 3 . Tax relief in relation to the cost of maintaining and improving the status of cultural and historical heritage. The appropriate version of the reporting form should be based on the selected criteria that give rise to the right to the benefit and its value. Both the experience of preferential taxation in highly developed countries and the real state of cultural heritage in Ukraine should be used. One option can be taken based on the methods of depreciation. It is not about depreciation of such assets (not subject to depreciation), but only the calculation of the value of the tax benefit using the depreciation rates. The variation in the method used depends on the state of the object: the accelerated depreciation method for destroyed more than $50 \%$ of the objects, and straightforward when less than that fraction. An important component of the provision of information on the state of cultural and historical heritage is to anticipate the involvement of local authorities and the population of the territories to control and monitor the qualitative changes of cultural heritage objects. Such information should be an integral part of assessing the credibility of the entities' accounting records.

The revision of the Ukrainian legislation in the sphere of formation of the system of preservation of cultural heritage provides for specific practical tasks of the Cabinet of Ministers of Ukraine, which also cover the prospects of cross-border cooperation (Table 3 ).

Table 3
The tasks of the Cabinet of Ministers of Ukraine for the preservation
of cultural heritage and its cross-border perspectives are outlined

\begin{tabular}{|l|l|}
\hline \multicolumn{1}{|c|}{ Tasks of intra-state character } & \multicolumn{1}{c|}{ Cross-border prospects } \\
\hline \multicolumn{1}{|c|}{1} & \multicolumn{1}{|c|}{2} \\
\hline $\begin{array}{l}\text { Creation of an effective system of protection of cultural } \\
\text { heritage, identification and use of its economic, tourist, } \\
\text { cultural and educational potential }\end{array}$ & $\begin{array}{l}\text { Introduce a system of public-private partnership in the } \\
\text { field of cultural heritage protection and promote } \\
\text { investment in this field, develop cooperation with } \\
\text { international organizations in the implementation of } \\
\text { grant support and implementation of projects }\end{array}$ \\
\hline $\begin{array}{l}\text { Ensure the creation of a National Geospatial Data } \\
\text { Infrastructure }\end{array}$ & $\begin{array}{l}\text { Ensure the introduction of Ukrainian cultural heritage } \\
\text { records abroad }\end{array}$ \\
\hline $\begin{array}{l}\text { To approve the Concept of reforming state policy in the } \\
\text { field of cultural heritage protection }\end{array}$ & $\begin{array}{l}\text { Strengthen state control over the export of cultural } \\
\text { property, in particular by monitoring auctioning }\end{array}$ \\
\hline
\end{tabular}

Continuation of table 3 


\begin{tabular}{|c|c|}
\hline 1 & 2 \\
\hline $\begin{array}{l}\text { To approve the State Program for the Protection of } \\
\text { Cultural Heritage for } 2019-2025\end{array}$ & $\begin{array}{l}\text { Enhance the participation of Ukraine in international } \\
\text { cooperation on the return of cultural values }\end{array}$ \\
\hline $\begin{array}{l}\text { To approve the National Target Program for } \\
\text { Preservation of Documents of the National Archival } \\
\text { Fund }\end{array}$ & $\begin{array}{l}\text { To intensify cooperation with UNESCO on the } \\
\text { inclusion of cultural heritage of Ukraine in the World } \\
\text { Heritage List }\end{array}$ \\
\hline $\begin{array}{l}\text { To provide completion and gradual commissioning of } \\
\text { the complex of buildings of the central state archives of } \\
\text { Ukraine in the city of Kiev }\end{array}$ & $\begin{array}{l}\text { Include objects of intangible cultural heritage in } \\
\text { UNESCO's lists of intangible cultural heritage }\end{array}$ \\
\hline $\begin{array}{l}\text { Ensure the preservation of the complete collection of } \\
\text { the Central State Archives-Museum of Literature and } \\
\text { Art of Ukraine }\end{array}$ & $\begin{array}{l}\text { Ensure the implementation of the decisions of the } \\
\text { UNESCO World Heritage Committee }\end{array}$ \\
\hline $\begin{array}{l}\text { Complementing the regional state administrations with } \\
\text { a structural unit on cultural heritage protection }\end{array}$ & $\begin{array}{l}\text { Establish cooperation with the UNESCO monitoring } \\
\text { mission to monitor the conservation of the World } \\
\text { Cultural Heritage in the Autonomous Republic of } \\
\text { Crimea }\end{array}$ \\
\hline \multicolumn{2}{|l|}{$\begin{array}{l}\text { To enter into the State Register of immovable } \\
\text { monuments of Ukraine of national importance the } \\
\text { objects of cultural heritage, taken into account before } \\
\text { the adoption of the Law "On Protection of Cultural } \\
\text { Heritage" }\end{array}$} \\
\hline $\begin{array}{l}\text { Together with the National Academy of Arts of Ukraine } \\
\text { to create a Research Institute of Museum Studies and } \\
\text { Restoration }\end{array}$ & \\
\hline
\end{tabular}

As can be seen from Table 3, part of the tasks of the internal state character is envisaged to carry out complex, consistent and coordinated activities to create an effective system of protection of cultural heritage, including intangible objects. Particular attention is paid to identifying and making effective use of economic, tourist, cultural and educational potentials and other cultural heritage potentials. It is necessary to establish a National Geospatial Data Infrastructure and to approve a number of documents, namely: The concept of reforming state policy in the field of cultural heritage, in which decentralization of management should be envisaged, leaving coordination and control functions to the central executive bodies, which provide the formulation and implementation of the state policy. in the field of cultural heritage protection; State Program for Protection of Cultural Heritage for 2019-2025 (immovable objects of cultural heritage, cultural values, elements of intangible cultural heritage) and State Target Program for preservation of documents of the National Archival Fund.

Internal tasks include completion of commissioning of the complex of the Central State Archives of Ukraine in Kyiv, maintenance of the complete collection of the Central State ArchivesMuseum of Literature and Art of Ukraine, as well as ensuring the introduction of changes to the recommended lists of structural subdivisions of oblast, Kyiv and Sevastopol, city, district in Kyiv and Sevastopol state administrations, approved by the Cabinet of Ministers of Ukraine of April 18, 2012 No. 606, supplementing ics structural unit for the protection of cultural heritage. Among this group of tasks it is envisaged to enter into the State Register of immovable monuments of Ukraine by category of national importance cultural heritage objects, taken into state account in accordance with the legislation that was in force before the Law of Ukraine "On Protection of Cultural Heritage" came into force, and to provide together with the National Academy of Arts of Ukraine to establish the Research Institute of Museum Studies and Restoration.

The tasks of cross-border cooperation include the introduction of a public-private partnership in the field of cultural heritage protection and the promotion of investment in the field of cultural heritage conservation, development of cooperation with international organizations in the implementation 


\section{Shvets}

of grant support and project implementation. Accounting for Ukrainian cultural heritage abroad should be ensured, as well as steps taken to strengthen state control over the export of cultural property, in particular by monitoring stationary and online auctions of antiques and cultural assets abroad. For these purposes, it is envisaged to allocate funds from the state budget. It is also envisaged to intensify Ukraine's participation in international cooperation on the return of cultural property and to intensify cooperation with UNESCO on the inclusion of cultural heritage sites of Ukraine in the UNESCO World Heritage List and intangible cultural heritage sites - in
UNESCO's Lists of Intangible Cultural Heritage Of the UNESCO World Heritage Committee. One of the tasks is to establish close cooperation with the UNESCO monitoring mission, the task of which is, inter alia, to monitor the conservation of the World Cultural Heritage in Crimea. In accounting and analytical aspect, the issue of accounting for objects of intangible cultural heritage is at the forefront, which to date is only beginning to be elaborated in the methodological plan.

An important area of activity for the safety and protection of cultural heritage is the task for the Ministry of Culture of Ukraine (Table 4).

\section{Tasks for the protection of cultural heritage for the Ministry of Culture of Ukraine and their accounting and analytical aspects}

\begin{tabular}{|c|c|c|}
\hline No. & Contents of tasks & Accounting and analytical aspects \\
\hline 1 & $\begin{array}{l}\text { Introduce international experience in the field of } \\
\text { cultural heritage, including intangible ones }\end{array}$ & $\begin{array}{l}\text { Accounting, evaluation and classification of } \\
\text { cultural objects }\end{array}$ \\
\hline 2 & $\begin{array}{l}\text { Ensuring completion of the State Register of Immovable } \\
\text { Monuments of Ukraine, the State Register of National } \\
\text { Cultural Property, the National List of Elements of the } \\
\text { Intangible Cultural Heritage of Ukraine }\end{array}$ & $\begin{array}{l}\text { Accounting, evaluation and registration of } \\
\text { cultural objects }\end{array}$ \\
\hline 3 & $\begin{array}{l}\text { Ensuring the development of legal mechanisms of } \\
\text { the creation and functioning of an electronic } \\
\text { information resource of cultural heritage and } \\
\text { cultural values. }\end{array}$ & Accounting and analytical procedures software. \\
\hline 4 & $\begin{array}{l}\text { Together with Cherkasy regional state. the } \\
\text { administration to create a historical and cultural } \\
\text { reserve "Simirenko Family" in the village. Mliiv } \\
\text { Gorodishche district Cherkasy region }\end{array}$ & $\begin{array}{l}\text { Accounting and registration of the objects of the } \\
\text { reserve }\end{array}$ \\
\hline 5 & $\begin{array}{l}\text { Ensure improvement of the system of annual } \\
\text { reporting of cultural heritage bodies }\end{array}$ & Formation of reporting methodology \\
\hline 6 & $\begin{array}{l}\text { Monitoring the state of storage of immovable objects } \\
\text { of cultural heritage, cultural values of Ukraine in the } \\
\text { temporarily occupied territories }\end{array}$ & $\begin{array}{l}\text { Control-analytical methods of control and } \\
\text { monitoring }\end{array}$ \\
\hline 7 & $\begin{array}{l}\text { Elaboration of the Draft Law of Ukraine on } \\
\text { Amendments to the Law "On Protection of Cultural } \\
\text { Heritage" and other legislative acts in the field of } \\
\text { protection of cultural heritage on implementation of } \\
\text { effective accounting of objects of cultural heritage, } \\
\text { creation of preconditions for the functioning of the } \\
\text { State Register of Cultural Heritage of Ukraine }\end{array}$ & $\begin{array}{l}\text { Methods of accounting and registration of } \\
\text { cultural heritage objects }\end{array}$ \\
\hline 8 & $\begin{array}{l}\text { Developing and approving the procedure for defining } \\
\text { and amending the boundaries and regimes for the use } \\
\text { of cultural heritage sites }\end{array}$ & $\begin{array}{l}\text { Analytical methods for monitoring the status of } \\
\text { cultural heritage monuments }\end{array}$ \\
\hline
\end{tabular}

As can be seen from Table 4, the Ministry of Culture of Ukraine is tasked with introducing international experience in the field of cultural heritage protection, ensuring state registration of all cultural heritage of Ukraine, as well as developing a legal mechanism for the functioning of the 
electronic information resource of cultural heritage and cultural values. The task of creating a historical and cultural reserve "Family of Simirenko" in the village of Mliiv, Gorodishche district, Cherkasy region. Particular attention is paid to improving the system of annual reporting of cultural heritage bodies. Quite a difficult task of monitoring the state of storage of immovable objects of cultural heritage, cultural values of Ukraine in the temporarily occupied territories of Ukraine, as well as the collection of information on the movement of museum objects of the state part of the Museum Fund of Ukraine stored in museums in temporarily occupied territories of Ukraine. The legislative plan envisages the development of the draft amendments to the Law of Ukraine "On Protection of Cultural Heritage" and some legislative acts in the field of cultural heritage protection regarding the introduction of effective accounting of cultural heritage objects, creation of preconditions for the functioning of the State Register of Cultural Heritage of Ukraine as an electronic information system, simplification systems for providing administrative services and deregulating relations in the field of cultural heritage protection, establishing the procedure for granting permits, approvals and visas ovkiv bodies of cultural heritage. Changes are planned to the Procedure for determining the categories of monuments for the entry of cultural heritage objects in the State Register of Immovable Monuments of Ukraine, approved by the Decree of the Cabinet of Ministers of Ukraine of December 27, 2001 No. 1760 and the Procedure for concluding protective contracts for cultural heritage monuments Resolution No. 1768 of the Cabinet of Ministers of Ukraine of December 28, 2001.

The development also provides for the procedure for defining and approving the boundaries and regimes for the use and amendment of cultural heritage sites; changes to the Procedure for accounting of cultural heritage objects; the procedure for informing the UNESCO World Heritage Committee of the intention to carry out urban, architectural and landscape changes, reclamation, road, earthworks at the World Heritage Site, its territory, in the buffer zone; instruction on exercising control over the implementation of the Law of Ukraine "On the
Protection of Cultural Heritage" and other normative legal acts in the field of cultural heritage protection; methodological recommendations for the inclusion of objects of intangible cultural heritage, both in the National list of elements of intangible cultural heritage of Ukraine and in the lists of intangible cultural heritage of UNESCO. As can be seen from the table. 4, accounting and analytical aspects pervade virtually most tasks, and this is especially true of intangible cultural heritage objects.

Together, the Ministry of Education and Science and the Ministry of Culture of Ukraine have been assigned the task of providing training in the field of cultural heritage protection and training of employees in the fields of cultural heritage, museum work, transfer and return of cultural property.

The intangible cultural heritage of Ukraine is a relatively new issue in the national scientific literature. UNESCO has issued a number of important acts in this respect, in particular, in 1989 the Recommendations for the Preservation of Traditional Culture and Folklore were adopted, the World Declaration on Cultural Diversity was adopted in 2001, and the Convention for the Protection of the Intangible Cultural Heritage was approved in 2003. Ukraine supported the UNESCO initiative and voted in favor of adopting the Convention on the Safeguarding of the Intangible Cultural Heritage; since 2004, the process of Ukraine's accession to the said Convention has begun, which included a procedure for discussing and adopting the relevant law in 2008. [7].

For the purposes of this Convention, the term "intangible cultural heritage" means those customs, forms of expression and expression, knowledge and skills, and related instruments, objects, artifacts and cultural spaces that are recognized by communities, groups and in some cases by individuals as part of their cultural heritage. This intangible cultural heritage, passed down from generation to generation, is constantly reproduced by communities and groups under the influence of their environment, their interaction with nature and their history, and they create a sense of identity and continuity, thereby promoting respect for the cultural diversity and creativity of man. For the purposes of this Convention, only 


\section{Shvets}

intangible cultural heritage compatible with existing international human rights treaties, with the requirements of mutual respect between communities, groups and individuals, as well as sustainable development, shall be taken into account. The term "intangible cultural heritage" in such areas:

- oral traditions and forms of expression, including in language as carriers of intangible cultural heritage;

- performing arts;

- customs, ceremonies, celebrations;

- knowledge and practice relating to nature and the universe;

- traditional crafts.

With the accession to the Convention for Ukraine the issues of scientific research, concerning the preservation and promotion of traditional folk culture, have become of particular importance. Accordingly, the preservation of the wealth of Ukrainian folk culture - the basis of the intangible cultural heritage - is one of the priority tasks of national importance, where the values of the culture of the border territories, and in particular of Poland, occupy a significant place.

As part of the implementation of the Convention, the regulatory framework is being constantly improved, namely:

1) in 2013 the Expert Council on Intangible Cultural Heritage under the Ministry of Culture of Ukraine was established as a permanent advisory and advisory body;

2) in 2015, the Ukrainian Center for Cultural Research was established, which is authorized to engage in scientific and methodological support for the implementation of the Convention on the Protection of the Intangible Cultural Heritage;

3) in 2017 the annual Prize for the preservation and protection of the intangible cultural heritage was launched, as well as the Procedure for maintaining the National list of elements of the intangible cultural heritage of Ukraine (Table 5) [8].

National list of objects of intangible cultural heritage of Ukraine

\begin{tabular}{|c|l|l|}
\hline No. & \multicolumn{1}{|c|}{ Code } & \multicolumn{1}{c|}{ Cultural heritage object } \\
\hline 1 & $001 . n k s$ & Tradition of Kosiv hand-drawn pottery \\
\hline 2 & $002 . n k s$ & Krolevets Overcome Weaving \\
\hline 3 & $003 . n k s$ & Opishnan ceramics \\
\hline 4 & $004 . n k s$ & $\begin{array}{l}\text { Petrykivsky painting - Ukrainian decorative and ornamental painting of XIX-XXI } \\
\text { centuries. }\end{array}$ \\
\hline 5 & $005 . n k s$ & Cossack songs of Dnipropetrovsk region \\
\hline 6 & $006 . n k s$ & Song tradition of Luka village in Kyiv-Svyatoshinsky district of Kyiv region \\
\hline 7 & $007 . n k s$ & $\begin{array}{l}\text { The technology of embroidery "white on white" settlement Reshetilovka Reshetilov } \\
\text { district of Poltava region }\end{array}$ \\
\hline 8 & $008 . n k s$ & Traditions of plant carpet of Reshetilovka village Reshetilov district of Poltava region \\
\hline 9 & $009 . n k s$ & Ornek - Crimean Tatar ornament and knowledge about it \\
\hline 10 & $010 . n k s$ & Tradition of ornamental painting of tambourine pottery \\
\hline 11 & $011 . n k s$ & Foster care \\
\hline 12 & $012 . n k s$ & Tradition of Hutsul Easter egg \\
\hline 13 & $013 . n k s$ & $\begin{array}{l}\text { The tradition of cooking et ayaklak (Karaite meat pie). Experience of Karaites of } \\
\text { Melitopol }\end{array}$ \\
\hline 14 & $014 . n k s$ & $\begin{array}{l}\text { Tradition of the "Driving the Bush" rite in the village of Svarticevichi, Dubrovytsia } \\
\text { district, Rivne region }\end{array}$ \\
\hline
\end{tabular}

As can be seen from Table 5, as of December 7, 2018, 14 elements of intangible cultural heritage are included in the National List.
Since 2018, the Ministry of Culture has been working with Google Ukraine on the preparation of the Intangible Cultural Heritage online resource, 
which is part of the Authentic Ukraine project, which already includes 3D tours of the Museums of Ukraine in the Sky, Wooden the churches of the Carpathian region ", Opera houses". According to the decision of the 8th session of the Intergovernmental Committee in 2013, the element "Petrykivsky painting - Ukrainian decorative and ornamental painting" is included in the Representative list of the intangible cultural heritage of mankind. At the 11th session of the Intergovernmental Committee in 2016, the element Cossack songs of Dnipropetrovsk, or "Cossack songs" - the phenomenon of performance of steppe songs (Ukrainian Cossack songs) in the Dnipropetrovsk region is included in the List of intangible cultural heritage that needs UNESCO. This element needs further protection as it faces a number of threats that could lead to its disappearance in the near future. These threats can be divided into two categories. The first is external threats. Thus, the members of the element mark the weak attention of state bodies, mass media, educational centers to the element "Cossack songs", which creates a similar attitude to this element to members of local communities as unimportant, not worthy of attention and conservation. The second is internal threats. The Cossack song element is threatened by a sharp reduction in the media of this element, which is related to the age category of the people who own (practice) this element. For the most part, these are people who are 80 years of age or older.

In 2018, the Ministry of Culture submitted the nomination dossier "Tradition of Kosovan hand-drawn ceramics" for consideration by the next session of the Intergovernmental Committee for inclusion in the Representative list of the intangible cultural heritage of humanity. This item was included in the National List for 2012. This element is an integral part of the intangible cultural heritage of Ukraine and is represented by Hutsuls, an ethnographic group of Ukrainians, who has long lived in the Carpathians of Ukraine and has best preserved its ethnographic and everyday traditions, along with other sub-ethnic groups of Ukrainians. This tradition developed from the end of the eighteenth century. in three sub-mountain centers: p. Pistyn, Kosiv (with the villages of Monastyrskoye, Moskalivka, Stary Kosiv, Smodnoe, Verbovets), Kuty and Staro Kuty. The Ministry of Culture of Ukraine continuously conducts seminars and conferences aimed at addressing a number of tasks related to the implementation of the above mentioned Convention, and in particular concerning the identification, identification, documentation, preservation, reproduction and promotion of intangible cultural heritage by particular regions.

At the same time, the codification of intangible cultural objects is far from perfect. For example: 006.nks object Song tradition of Luka village of Kiev-Svyatoshinsky district of Kyiv region - so it seems that only one village of Ukraine has song and song traditions. Why not single out the individual regions with their song traditions in the code of the next extended order. After all, there are accounting bases and a plan of accounts that provides bills, subaccounts, and for specific entities analytical accounts. Also object 007.nks The technology of embroidery "white on white" settlement Reshetilovka Reshetilov district of Poltava region. And black and red on white is not a tradition? There are different regions and all of their traditions, which are often unique. The necessity to improve the generally accepted classification criteria is conditioned by the inadequate presentation of intangible assets of the cultural and historical heritage in the regional context, ignoring and unacceptable muting of unregistered objects of NAKIS Ukraine. Obviously, this concerns the unscientific mixing of different disparate and incomparable classification criteria (rite and preparation of pies). Monoculture does not mean mixing, it means the existence of parallel cultures, their recognition in the context of traditions. Therefore, it is necessary to classify according to the established standards of international accounting standards, and not invent the wheel, suppressing unreasonably registered objects of accounting. Such features of the classification may be activities: dance, song, cooking, etc., and these types will imply multiculturalism [9]. This approach will make it possible to isolate intangible objects on the border with Poland. 


\section{Shvets}

Accounting and analytical problems of cultural heritage safety have a faster prospect of solution with proper professional training of specialists of the respective specialties. Important, in our opinion, is the organization of field studies of future specialists involved in the preservation and protection of cultural heritage. For example, an expert survey conducted in the first half of 2019 among students of the Faculty of Economics of Lviv National University. Ivan Franko stationary and correspondence forms of study, allowed to establish a relation for the purpose to determine the level of awareness and perception of antiques by future accountants. In order to obtain information, surveys were conducted in the form of questionnaires, in particular such questions as perceptions of cultural values, antiques and collectibles.

For example, regarding the timing of antiques, most of the 122 students surveyed consider it appropriate to refer objects that are more than 100 years old $(55.74 \%)$, more than 50 years old $-40.98 \%$, and more than 25 years old $-7.38 \%$.

When asked, does Ukraine need a special regulatory framework for trade in collectibles and antiques? 106 people answered in the affirmative $(86.88 \%)$; difficult to say answered 11 people $(9.02 \%)$ and 5 people $(4.1 \%)$ believe that separate legislation is not required.

The question whether in Ukraine it is advisable to classify collectibles and antiques in the same way as in EU countries, whether it is necessary to develop their classification criteria for accounting, analysis and control purposes, taking into account the specific features of cultural and historical heritage, 69 people answered affirmatively $(56.56 \%)$. it is expedient to use the classification 43 persons $(35.24 \%)$ agreed and do not know 10 persons $(8.2 \%)$.

\section{Conclusions}

Accounting and analytical problems of cultural heritage security in Polish-Ukrainian crossborder cooperation take place and are conditioned by the process of improvement of legal regulation in Ukraine. They concern, first and foremost, the correct perception of cultural objects, the fair assessment and the proper classification of the individual components. A number of measures need to be taken to address these issues, namely:

First, theoretical and methodological research requires standardization of the classification parameters of cultural heritage objects on the Polish-Ukrainian border, taking into account national priorities of their perception and local mental-traditional norms. This will be facilitated by the creation of registers of cultural heritage objects by qualification groups, namely: prominent figures of Polish and Ukrainian identity born in the border area; objects of tangible cultural and historical heritage; objects of intangible cultural and historical heritage.

Secondly, it is necessary to develop a methodology for the objective evaluation of cultural heritage objects that would effectively reflect their real value, taking into account the prospects of world cultural and historical progress, as well as in the border areas of Poland and Ukraine. The development of such a method has the potential to create in the near future a separate standard for the account of objects of cultural and historical heritage and antiques.

Thirdly, in view of the Resolution adopted by the Verkhovna Rada of Ukraine "State, Problems and Prospects for the Protection of Cultural Heritage in Ukraine" of 14.05.2019, there is a need for more specific measures for the formation of a security system for the protection of cultural heritage in the border area. The solution to these problems involves taking into account the higher level achieved in Poland in the legal field, Polish practical experience, as well as initiatives concerning the preservation and protection of the common cultural and historical heritage in the border area.

Fourthly, on the basis of an expert survey among students - future specialists in the field of accounting and taxation, their accounting and analytical perception of cultural heritage objects and problems, as to their condition and preservation, were found out. Conducted questionnaire will help to draw attention to the issues of trade in antiques, as objects of accounting that are 
directly related to the cultural and historical heritage and its security. This will help to focus students' attention on cultural heritage in further professional training.

As the Cabinet of Ministers of Ukraine must keep the Verkhovna Rada of Ukraine constantly informed about the state of implementation of the recommendations approved by the aforementioned Resolution, it is therefore possible and necessary to use the proposed initiatives and the above results of scientific research.

\section{References}

1. Shvets V. Some aspects of the Ukrainian-Polish cross-border cooperation in the field of control for the conservation of cultural and historical values / Contemporaary Socio-Economic Issues of PolishUkrainian Cross-border Cooperation // Publication of the Scientific Papers of the International Scientifik Conference. Center of Europian Projects, Warsaw 2017. P. 15-37.

2. Modeling of economic security: state, region, enterprise: monogr / V. M. Geets, M. O. Kizim, T.S. Klebanova, O. I. Chernyak. H.: INZHEK, 2006. 240 p. [in Ukrainian].

3. Theoretical and methodological principles of formation of organizational support of economic safety management of machine-building enterprise: monogr / O. V. Khalina, A. M. Stangret, L. E. Sukhomlin, O. V. Melnikov; for the total. ed. A. M. Shtangret. Lviv: Ukr. Acad. printing, 2016. 220 p. [in Ukrainian].

4. Open letter to the museum and monumental community of Ukraine, Retrieved from: https://www. facebook.com/ucrms/posts/2374828805913724. [in Ukrainian].

5. Resolution of the Verkhovna Rada of Ukraine On Recommendations of Parliamentary Hearings on: "State, Problems and Prospects for the Protection of Cultural Heritage in Ukraine", No. 2716-VIII of 14.05.2019. p. Retrieved from: https://zakon. rada.gov.ua/laws/show/2716-viii. [in Ukrainian].

6. The Constitution of Ukraine. Retrieved from: https://zakon.rada.gov.ua/laws/show/254\%D0\%B A/96- \%D0 \%B2 \%D1 \%80. [in Ukrainian].

7. Law of Ukraine "On Accession of Ukraine to the Convention for the Protection of the Intangible Cultural Heritage” of 06.03.2008 № 132. Retrieved from: https://zakon.rada.gov.ual laws/show/ 132-17. [in Ukrainian].

8. Intangible cultural heritage of Ukraine. Retrieved from: http://mincult.kmu.gov.ua/control/uk/publish/ Marticle?art_id $=245154362 \&$ cat_id $=245154164$. [in Ukrainian].

9. Nezhigay I. Seven new cultural sites included in the UNESCO World Heritage List. Retrieved from: https://www.unn.com.ua/uk/news/1811498-simnovikh-kulturnikh-obyektiv-vneseni-do-spiskuvsesvitnoyi-spadschini-yunesko. [in Ukrainian]. 